\title{
HALLGATÓI TANULMÁNYI EREDMÉNYEK MÉRÉSE ÉS ÖSSZEHASONLÍTÁSA DUÁLIS - NEM DUÁLIS VISZONYLATBAN
}

\section{MEASUREMENT AND COMPARISON OF STUDENT LEARNING OUTCOME RESULTS IN A DUAL - NON- DUAL RELATION}

\author{
Dr. Török Erika ${ }^{1^{*}}$, Angeli Eliza ${ }^{2}$ Noel Gáborné ${ }^{3}$ \\ ${ }^{1}$ Informatika Tanszék, GAMF Müszaki és Informatikai Kar, Neumann János Egyetem, Magyarország \\ 2 Innovatív Járművek és Anyagok Tanszék, GAMF Műszaki és Informatikai Kar, Neumann János Egyetem, \\ Magyarország \\ ${ }^{3}$ Oktatási Igazgatóság, Neumann János Egyetem, Magyarország \\ https://doi.org/10.47833/2020.3.ART.007
}

\section{Kulcsszavak: \\ duális képzés \\ hallgatói tanulmányi eredmények \\ kreditindex \\ munkaerö-piac \\ felsőoktatás minősége \\ Keywords: \\ dual education \\ student learning outcomes \\ credit index \\ labor market \\ quality of higher education}

\section{Cikktörténet:}

Beérkezett

Átdolgozva

Elfogadva
2020. október 28.

2020. október 30.

2020. október 31.

\section{Összefoglalás}

Magyarországon a duális képzési formát a felsőoktatási intézmények közül elsőként a Neumann János Egyetem indította el 2012-ben. Az új típusú képzésben 24 jármümérnök szakos hallgató kezdte meg tanulmányait. Idővel egyre több képzési területen - müszaki, informatikai, agrár; gazdasági -, és egyre több alapszakon indítottuk el a duális képzést. A 2020-2021-es tanévben 10 alapszakon 295 számú hallgató tanul duális formában egyetemünkön. Hallgatókat foglalkoztató partnereink száma a kezdeti kettőröl 48-ra emelkedett. Az elmúlt 8 évre visszatekintve fontosnak tartjuk, hogy eddigi eredményeiket áttekintsük és elemezzük. Jelen tanulmányban az oktatás minőségéhez kapcsolódóan a duális és nem duális hallgatók tanulmányi eredményeit vizsgáljuk. Bízunk benne, hogy elemzésünk segítheti mind a duális, mind a normál képzés fejlesztését.

\begin{abstract}
In Hungary, the dual form of higher education was first launched by John von Neumann University in 2012. In the new type of training, 24 students began their studies in vehicle engineering course. Over time, we started more and more types of dual training - technical, IT, agricultural; economic - and also dual basic courses. In the 2020-2021 academic year, 295 students in 10 basic courses study in dual form at our university. The number of our dual partners has increased from the initial two to 48. Looking back over the past 8 years, we consider, that it's important to review and analyze their results to date. In this study, we investigate the learning outcome of dual and non-dual students in relation to the quality of education. We hope that our
\end{abstract}

\footnotetext{
${ }^{*}$ Kapcsolattartó szerző. Dr. Török Erika Tel.: +36 202653132

E-mail cím: torok.erika@gamf.uni-neumann.hu
} 
trainings.

\section{Bevezetés}

Magyarországon a duális képzési formát a felsőoktatási intézmények közül elsőként a Neumann János Egyetem indította el 2012-ben. Ekkor a duális képzésben 24 jármümérnök szakos hallgató kezdte meg tanulmányait. Idővel egyre több képzési területen (a müszaki mellett informatikai, agrár; gazdasági) és alapszakon (gépészmérnöki, jármümérnöki, logisztikai mérnöki, mérnökinformatikus, gazdálkodás és menedzsment, kereskedelem és marketing, nemzetközi gazdálkodás, pénzügy és számvitel, kertészmérnöki, vidékfejlesztési agrármérnöki, mezőgazdasági mérnök) indítottuk el a duális képzést. Ezáltal természetesen egyre több hallgató léphetett be ebbe a típusú képzésbe. A 2020-2021-es tanévben 10 alapszakon 295 számú hallgató tanul duális formában. Hallgatókat foglalkoztató partnereink száma a kezdeti kettőről 48-ra emelkedett. Az elmúlt 8 évre visszatekintve fontosnak tartjuk, hogy eddigi eredményeiket áttekintsük és elemezzük. Jelen tanulmányban az oktatás minőségéhez kapcsolódóan a duális és nem duális hallgatók tanulmányi eredményeit vizsgáljuk.

\section{A duális képzés eredményességének lehetséges mérőszámai}

A duális képzés eredményességének vizsgálata számtalan szempont, mérőszám szerint történhet. Többek között lehetséges a hallgatói nem kognitív képességek vizsgálata [11], a munkaerő-piaci elvárások [3], a hallgatói önreflexiós képesség [8], a hallgatói elégedettség [13], hallgatói motiváció [12], a hallgatói lemorzsolódás [14]. Mások szerint az eredményesség szempontjából fontos a tanulmányi átlag, a kreditek száma, és a tanulmányok melletti kitartás [1], [9].

Kutatásunkban a képzés elindításakor kialakított rendszerhez, az un. „Felsőfokú duális képzés - Intézményi Fehér Könyv" című dokumentumban meghatározott mérőszámokhoz kívánunk igazodni, mert így látjuk következetesnek az eddigi eredmények követését [4] [6]. Az Intézményi Fehér könyv szerint a képzés eredményességét mérhetjük a (1) képzések elterjedtségével, (2) a duális partnerekkel kapcsolatos együttműködések számával, a (3) képzéssel kapcsolatos elégedettséggel és a (4) minőségi oktatás jellemzőinek vizsgálatával.

Képzések elterjedtségének (1) mérőszámai a duális képzésbe bevont képzések száma $(\mathrm{db})$ és a képzésekbe beiskolázott hallgatói létszám (fö). $A$ duális partnerekkel történő együttműködés (2) méröszámai a duális partnerek száma (db vagy \%) és a duális partnerek elégedettsége (\%). A képzésekkel kapcsolatos elégedettség (3) mérőszámai a hallgatói elégedettség aggregált értéke (\%) és a lemorzsolódó hallgatók száma (fő vagy \%). A minőségi oktatás teljesítményének (4) méröszámai a duális hallgatók teljesítménye (\%) és a végzett és munkahelyre felvettek aránya (\%).

A hallgatói teljesítmény mérésének érdekében a továbbiakban a duális és nem duális hallgatók létszám adatait és tanulmányi eredményeit vizsgáljuk annak érdekében, hogy megállapításokat tegyünk a duális képzés eredményességére vonatkozóan.

\section{Mérö- és értékelö módszertan kidolgozása a duális hallgatók tanulmányi eredményének mérésére}

A duális képzés tanulmányi eredményekre gyakorolt hatásának elemzése érdekében strukturált mérő- és értékelő módszertant dolgoztunk ki.

Első lépésként a szükséges dokumentumok és a technikai (Neptun) háttért feltérképezését végeztük el. Meg kellett ismerkednünk azzal, hogy a hallgatók duális képzését a Neptun felületen hogyan kezelik, milyen adatokat tárolnak a hallgatóról, a képzésröl, a duális partner cégről.

Miután mindezeket áttekintettük, át kellett gondolni, hogy milyen információkra lesz szükségünk, hogy az adatgyüjtést el tudjuk kezdeni. Intézményünk már 2012-től kísérleti jelleggel bevezette ezt a képzési formát, de a tanulmányi rendszerbe csak a 2015/2016-os tanév őszi félévétöl lehetett ilyen típusú adatokat rögzíteni. Ezért is választottuk ki vizsgálatunk kezdő időpontjának a 2015/2016-os tanév őszi félévét. A célcsoportot ekkor még csak a GAMF Kar hallgató 
képezték, de később bekapcsoltuk a Gazdaságtudományi Kar és a Kertészeti és Vidékfejlesztési Kar hallgatóit is. Felmenő rendszerben 2015-től szakonként kigyűjtöttük a duális és nem duális hallgatók adatait a rendszerböl.

Következő lépésként meghatároztuk, hogy mely adatokra koncentrálunk, amelyek segítségével elemezni tudjuk a hallgatói teljesítményt. A munkálatok fontos lépése volt, hogy elkészítettünk egy „Adatbányász” értékelő programot “, mely alkalmas arra, hogy a lekért adatokat elemezzük. Miután a hallgatókat sikerült kigyüjteni a rendszerből, olyan adatokra koncentráltunk, melyek segítségével elemezni tudjuk majd a hallgatói teljesítményt. Ezért a következő adatokat választottuk: kreditindex, hagyományos átlag, felvett kredit, teljesített kredit, elismert kredit, göngyölt kredit, évfolyam, félév megnevezése.

Elsősorban a kreditindexre és a súlyozott tanulmányi átlagra fókuszáltunk, mert egzakt módon ezekkel az adatokkal tudjuk mérni a hallgatók tanulmányi teljesítményét.

Az Adatbányász program lekérdezéseivel féléves szinten nagyon sok féle értékelést készíthetünk. Lehetöség van kari eredményeket összehasonlítani, karon belül szakok közötti eredményeket összehasonlítani, illetve azonos lekérdezések eredményeit össze lehet vetni különböző félévekben, különböző szakokon.

A továbbiakban az adatokból mutatunk be néhányat egyrészt a hallgatói eredmények elemzése, értelmezése érdekében, másrészt abból a célból, hogy láthatóvá tegyük az elemzések lehetőségét a kollégák számára.

\subsection{Háttér információk az adatok értelmezéséhez}

Adott félévben a hallgató teljesítményének mennyiségi és minőségi megítélésére a kreditindexet használjuk. A kreditindex számítási módja: a félévben teljesített tantárgyak kreditértékének és érdemjegyének szorzataiból képzett összeget el kell osztani az egy félév alatt átlagos előrehaladás esetén teljesítendő kredittel (30 kredit).

A hallgató tanulmányi teljesítményének nyomon követésére a súlyozott tanulmányi átlag szolgál. A súlyozott tanulmányi átlag számítási módja: az adott időszakban (félév) teljesített tantárgyak kreditértékének és érdemjegyének szorzataiból képzett összeget a teljesített tantárgyak kreditjeinek összegével kell elosztani.

\section{Hallgatói tanulmányi létszámok és eredmények}

\subsection{A félévenkénti létszám adatok egyetemi szinten}

Az összesítésekböl kiderült, hogy egyetemi szinten a duális hallgatók létszáma tanévenként növekedést mutat. Az évenkénti adatok szignifikáns összefüggést mutatnak $\left(X^{2}=826,278 ; p<0,001\right)$. A legnagyobb növekedést mindig az őszi félévek kezdete hozott, ugyanis a duális képzésbe az őszi félév kezdetén lehet bekapcsolódni. Ahogy egyre ismertebbé vált a duális képzés, valamint egyre több szakon indítottuk ilyen formában is a képzéseinket, valamint ahogy a duális partnerek száma is nött, úgy növekedtek a duális hallgatói létszámok is (1. táblázat). Mindezek mellett a duális hallgatói létszám változására is érvényesek azok a hatások, amelyek a normál hallgatói létszámadatokat befolyásolják.

1. Táblázat. 4.1. A félévenkénti létszám adatok egyetemi szinten (2015-2019 között)

\begin{tabular}{|c|c|c|c|}
\hline Félév & Duális hallgatói létszám & Nem duális hallgatói létszám & $\begin{array}{c}\text { Összes hallgatói } \\
\text { létszám }\end{array}$ \\
\hline $2015 / 16 / 1$ & 63 & 1885 & 1948 \\
\hline $2015 / 16 / 2$ & 62 & 1572 & 1634 \\
\hline $2016 / 17 / 1$ & 141 & 1606 & 1747 \\
\hline $2016 / 17 / 2$ & 137 & 1278 & 1415 \\
\hline
\end{tabular}

* Köszönet Devosa Ivánnak az adatbázis elkészítéséért. 


\begin{tabular}{|c|c|c|c|}
\hline $2017 / 18 / 1$ & 243 & 1362 & 1605 \\
\hline $2017 / 18 / 2$ & 236 & 1046 & 1282 \\
\hline $2018 / 19 / 1$ & 332 & 1144 & 1476 \\
\hline $2018 / 19 / 2$ & 293 & 890 & 1183 \\
\hline
\end{tabular}

Az 1. és 2. félévek közötti létszám csökkenés abból adódhat, hogy a hallgatók egy félév után már biztosan el tudták dönteni, hogy az a szigorú rend, amit a duális hallgatóknak követni kell, megfelelő-e számukra. Amennyiben ezt mégsem vállalják, akkor kiléphettek a duális képzés keretei közül. Tehát az alábbi táblázatból nyomon követhető a hallgatói lemorzsolódás is. Láthatjuk, hogy arányaiban a hallgatói lemorzsolódás lényegesen kisebb a duális, mit a nem duális hallgatók körében.

\subsection{A félévenkénti tanulmányi eredmények egyetemi szinten}

2015-16-os tanévtől kezdődően az alábbi eredményeket kaptuk a kreditindexek alapján az egyetem mindazon szakjaira vonatkozóan, amelyek duális formában is müködnek (2. táblázat).

2. Táblázat. A féléves kreditindex adatok 2015/16-2018/19 között

\begin{tabular}{|c|c|c|c|c|c|}
\hline Félév & $\begin{array}{c}\text { Duális hallgatói } \\
\text { kerditindex }\end{array}$ & $\begin{array}{c}\text { Nem duális } \\
\text { hallgatói } \\
\text { kerditindex }\end{array}$ & $\begin{array}{c}\text { Kreditindex } \\
\text { különbség }\end{array}$ & $\begin{array}{c}\text { Welch- } \\
\text { próba }(d)\end{array}$ & $\begin{array}{c}\text { Levene- } \\
\text { próba }(F)\end{array}$ \\
\hline $2015 / 16 / 1$ & 3,82 & 2,69 & 1,13 & 8,639 & 37,029 \\
\hline $2015 / 16 / 2$ & 3,38 & 2,56 & 0,82 & 6,610 & 37,916 \\
\hline $2016 / 17 / 1$ & 3,32 & 2,48 & 0,84 & 9,017 & 54,851 \\
\hline $2016 / 17 / 2$ & 3,88 & 2,66 & 1,22 & 10,326 & 43,211 \\
\hline $2017 / 18 / 1$ & 3,56 & 2,50 & 1,06 & 13,009 & 59,979 \\
\hline $2017 / 18 / 2$ & 3,69 & 2,46 & 1,23 & 15,307 & 111,740 \\
\hline $2018 / 19 / 1$ & 3,21 & 2,43 & 0,78 & 10,882 & 29,587 \\
\hline $2018 / 19 / 2$ & 3,63 & 2,58 & 1,05 & 12,177 & 48,543 \\
\hline
\end{tabular}

A különbség minden félév esetén szignifikáns. A Welch-próba mindegyik esetben $p<0,001$, de a két részmintában (duális, nem duális) a szórások (Levene-próba) is szignifikánsan eltérnek, azaz a nem duális hallgatók egyéni különbségei minden félévben nagyobbak.

A súlyozott tanulmányi átlagokat szintén azoknál a szakoknál vizsgáltuk, ahol duális képzés is müködik. Az adatok 2015-16-os tanévtöl kezdődően a 3. táblázatban láthatóak. A különbség itt is minden félév esetén szignifikáns. A Welch-próba mindegyik esetben $p<0,001$, és a két részmintában a szórások is szignifikánsan eltérnek, azaz a duális hallgatóknál a szórások jelentősen kisebbek, mint a nem duális hallgatóknál.

3. Táblázat. Súlyozott tanulmányi átlagok adatai 2015/16-2018/19 között

\begin{tabular}{|c|c|c|c|c|c|}
\hline Félév & $\begin{array}{c}\text { Duális hallgatói } \\
\text { súlyozott } \\
\text { tanulmányi átlag }\end{array}$ & $\begin{array}{c}\text { Nem duális } \\
\text { hallgatói } \\
\text { súlyozott } \\
\text { tanulmányi átlag }\end{array}$ & $\begin{array}{c}\text { Súlyozott } \\
\text { tanulmányi átlag } \\
\text { különbség }\end{array}$ & $\begin{array}{c}\text { Welch- } \\
\text { próba }(d)\end{array}$ & $\begin{array}{c}\text { Levene- } \\
\text { próba }(F)\end{array}$ \\
\hline $2015 / 16 / 1$ & 3,74 & 3,41 & 0,33 & 6,154 & 25,165 \\
\hline $2015 / 16 / 2$ & 3,46 & 3,07 & 0,39 & 6,505 & 31,146 \\
\hline $2016 / 17 / 1$ & 3,57 & 3,2 & 0,37 & 6,968 & 50,747 \\
\hline $2016 / 17 / 2$ & 3,68 & 3,17 & 0,51 & 7,149 & 39,508 \\
\hline $2017 / 18 / 1$ & 3,67 & 3,26 & 0,41 & 9,935 & 78,516 \\
\hline $2017 / 18 / 2$ & 3,79 & 3,16 & 0,63 & 12,705 & 108,804 \\
\hline $2018 / 19 / 1$ & 3,66 & 3,22 & 0,44 & 10,201 & 81,227 \\
\hline $2018 / 19 / 2$ & 3,65 & 3,12 & 0,53 & 10,202 & 101,477 \\
\hline
\end{tabular}


A kreditindex és a súlyozott tanulmányi átlagok összesítésekböl kiderült, hogy egyetemi szinten a duális hallgatók kreditindexe és súlyozott tanulmányi átlaga is félévröl félévre megelőzi a nem duális képzésben részt vevő hallgatókét. A duális képzésre jelentkező hallgatók erősen motiváltak, és kimondottan fontos számukra, hogy tanulmányaikat lehetöleg hét félév alatt teljesítsék.

\section{Következtetések}

A Neptun rendszeréből lekérhető elemzések alapján azt mondhatjuk, hogy a duális hallgatók tanulmányi eredményei átlagosan jobbak. Természetesen mind a két csoportban nagyok az egyéni különbségek. Összességében azokat a hallgatókat tekinthetjük eredményesnek, akik piacképes szaktudással, megfelelő kompetenciákkal rendelkeznek, s a megszerzett tudásukat kamatoztatni tudják a munkaerőpiacon. A duális hallgatók esetében a tanulmányi eredmények mellett jelentős szerepe van a munkavégzésnek, mint identitásképző tényezőnek is [10]. A tanulmányok alatti, szakmához kapcsolható kettős identitás - hallgatói és munkavállalói - pozitívan hat mind a tanulmányokra, mind a munkával kapcsolatos elköteleződésre [5]. Az egyetemre és a munkahelyre jellemző eltérő társadalmi környezet, eltérő tapasztalatok, tanulási és munkakultúra összességében erősen befolyásolja a későbbi munkaerő-piaci teljesítményt. A duális és nem duális hallgatók teljesítményének összehasonlítására külföldön más módszerek is elérhetők, melyekkel nyomon követhető, kiértékelhető a hallgatók szakmai fejlödése [2], [7]. Ezen módszerek áttekintése segítséget nyújthat a duális - nem-duális hallgatói teljesítmények összehasonlító módszertanának kidolgozásában is.

Tanulmányunkban az oktatás minőségéhez kapcsolódóan elsősorban a duális hallgatók tanulmányi eredményeit vizsgáltuk, hasonlítottuk össze nem duális hallgatók eredményeivel. Azt gondoljuk, azok az adatok, melyek a kialakított adatbázis segítségével elérhetők, további elemzésekhez nyújthatnak alapot, és segíthetik mind a duális, mind a normál képzés fejlesztését. A továbbiakban más szempontok, módszerek segítségével is szükséges a képzések sikerességének vizsgálata.

\section{Köszönetnyilvánítás}

Köszönettel tartozunk a kutatás támogatásáért, amely az EFOP-3.6.1-16-201600006 „A kutatási potenciál fejlesztése és bővítése a Neumann János Egyetemen" pályázat keretében valósult meg. A projekt a Magyar Állam és az Európai Unió támogatásával, az Európai Szociális Alap társfinanszírozásával, a Széchenyi 2020 program keretében valósul meg.

\section{Irodalomjegyzék}

[1] Astin, A. W. (1993): What matters in college? Four critical years revisited. Jossey-Bass Publishers, San Francisco, CA. DOI: $10.2307 / 1176821$

[2] Angeli, E., Török E., Nagy, D. (2018): Evaluation of students in dual higher education In: Bojan, Lalić (szerk.) Proceedings of TEAM 2018: 9th International Scientific and Expert Conference: 10-12th October 2018, Novi Sad, Serbia: Faculty of Technical Sciences, Department of Industrial Engineering and Management, pp. 257-262., 6 p. ISBN: 9788660220983 Google scholar

[3] Fazekas, K. (2018): Nem-kognitív készségek hiánya a munkaerőpiacon. Magyar Tudomány, 179/1. pp. 24-35. DOI: $10.1556 / 20$ 65.179. 2018.1 .3

[4] Felsőfokú duális képzés - Intézményi Fehér Könyv (2015)

[5] Kocsis, Zs. (2020): Az elmélet és a gyakorlat találkozása. Metszetek - társadalomtudományi folyóirat 9: 2 pp. 162166., 5 p. ISSN 2063-6415

[6] Kovacs, Zs., Török, E. (2016): Dual System for Renewing Hungarian Higher Education. International Journal of Education and Learning Systems, vol. 1, pp. 81-85 http://iaras.org/iaras/journals/ijels

[7] Nagy, D., Török, E., Angeli, E. (2019): A duális képzésű hallgatók szakmai fejlödésének követése és értékelése Gradus 6: 1 pp. 57-62. Paper: 07, 6 p.

[8] Pap-Szigeti, R., Török, E. \& Tánczikné Varga, Sz. (2018): Kérdőívek és tesztek elektronikus felvételét támogató szoftver fejlesztése és alkalmazása. In: Fodorné Dr. Tóth Krisztina (szerk.). A felsőoktatási lifelong learning 
társadalmi és gazdasági haszna: kutatás - fejlesztés - innováció. Pécs: MELLEARN. 21-30. o. ISBN 978-963-429221-0 http://mellearn.hu/wp-content/uploads/2018/11/teljes_v3.pdf

[9] Pascarella, E. T. \& Terezeni, P. T. (2005): How college affects students: Vol. 2. A third decade of research. JosseyBass Publishers, San Francisco, CA. DOI: 10.1353/csd.2006.0055

[10] Perna, L. (2010): Understanding the Working College Student New Research and Its Implications for Policy and Practice" Sterling: Stylus Publishers. https://doi.org/10.1111/j.1467-9647.2012.00815.x

[11] Pogátsnik, M.(2019): The Impact of Dual Higher Education on the Development of Non-Cognitive Skills. In: Kováts, G. -Rónay, Z.(eds.) In search of excellence in higher education. Budapest, pp. 179-190. http://unipub.lib.unicorvinus.hu/4132/1/Danube_kotet_cimlappal-2.pdf

[12] Török, E. (2017). A duális képzés felsőoktatásban betöltött innovációs szerepe. In: Fodorné Dr. Tóth Krisztina. Felsőoktatás, életen át tartó tanulás és az ENSZ fenntartható fejlesztési célok megvalósítása. Pécs: MELLEARN. 187-198. o. http://mellearn.hu/wp-content/uploads/2017/12/teljes_v6.pdf

[13] Török E., Pap-Szigeti R., Ailer, P., Palkovics, L. (2014): A Kecskēméti Főiskola duális képzésének monitoring vizsgálata a hallgatók visszajelzései alapján. A jövő járműve, 1-2, pp. 32-36. http://www.sze.hu/ jret/AJJ/AJJ_201412.pdf

[14] Zimányi, K. (2016). Duális képzés a gazdaságtudományi képzési területen, a BGE tapasztalatai. In: Fodorné Dr. Tóth Krisztina. Felsőoktatás, életen át tartó tanulás és az ENSZ fenntartható fejlesztési célok megvalósitása. Pécs: MELLEARN. 97-105. o. http://mellearn.hu/wp-content/uploads/2016/10/MELLearN_conference_2016.pdf 